\title{
Faktor Kritis Kesiapan E-Learning Pendorong Perfoma Belajar Ekonomi Siswa SMA Selama Pandemi Covid-19
}

\author{
Yohana Paramita*, Waspodo Tjipto Subroto \\ Program Studi Pendidikan Ekonomi, Fakultas Ekonomi Universitas Negeri Surabaya \\ *Corresponding Author. Email: yohanaxak5@gmail.com
}

\begin{abstract}
This study aims to analyze the effect of e-learning readiness factors, including self-competency, perceived usefulness, self-directed learning, motivation, and financial on the economic learning performance of high school students. This study used a quantitative approach. A total of 177 students were involved in this study. The data were collected through questionnaires and documentation. Regression analysis was used to analyze the data. The results of the study showed that four factors of e-learning readiness, namely selfcompetency, perceived usefulness, self-directed learning, and financial partially had a significant effect on students' economic learning performance (exam scores). Self-directed learning emerged as the strongest factor for driving students' economic learning performance (exam scores), and sequentially followed by self-competency, financial, and perceived usefulness factors. Another factor, namely motivation partially has no effect on students' economic learning performance (assignment and exam scores). Meanwhile, simultaneously all e-learning readiness factors have an effect on students' economic learning performance (assignment and exam scores).
\end{abstract}

\begin{abstract}
Abstrak: Penelitian ini bertujuan untuk menganalisis pengaruh faktor kesiapan e-learning, meliputi self-competency, perceived usefulness, self-directed learning, motivation, dan financial terhadap performa belajar ekonomi siswa SMA. Penelitian ini merupakan penelitian kuantitatif. Sebanyak 177 siswa terlibat dalam penelitian ini. Pengumpulan data dilakukan melalui kuesioner dan dokumentasi. Analisis regresi digunakan untuk melakukan analisis data. Hasil penelitian menunjukkan bahwa empat faktor kesiapan e-learning yakni selfcompetency, perceived usefulness, self-directed learning, dan financial secara parsial berpengaruh signifikan terhadap performa belajar ekonomi siswa (nilai ujian). Self-directed learning muncul sebagai faktor terkuat pendorong performa belajar ekonomi siswa (nilai ujian), dan kemudian secara berurutan diikuti oleh faktor self-competency, financial, dan perceived usefulness. Faktor lainnya yakni motivation secara parsial tidak berpengaruh terhadap performa belajar ekonomi siswa (nilai tugas dan ujian). Sedangkan, secara simultan seluruh faktor kesiapan e-learning berpengaruh terhadap performa belajar ekonomi siswa (nilai tugas dan ujian).
\end{abstract}

\section{Article History}

Received: 10-02-2021

Revised: 12-04-2021

Accepted: 22-04-2021

Published: 07-06-2021

\section{Key Words:}

E-Learning Readiness, Online Learning

Performance,

Economics Learning.

\section{Sejarah Artikel}

Diterima: 10-02-2021

Direvisi: 12-04-2021

Disetujui: 22-04-2021

Diterbitkan: 07-06-2021

\author{
Kata Kunci: \\ Kesiapan E-learning, \\ Performa Belajar \\ Online, \\ Pembelajaran Ekonomi.
}

How to Cite: Paramita, Y., \& Subroto, W. (2021). Faktor Kritis Kesiapan E-Learning Pendorong Perfoma Belajar Ekonomi Siswa SMA Selama Pandemi Covid-19. Jurnal Kependidikan: Jurnal Hasil Penelitian dan Kajian Kepustakaan di Bidang Pendidikan, Pengajaran dan Pembelajaran, 7(2), 314-327. doi:https://doi.org/10.33394/jk.v7i2.3499

https://doi.org/10.33394/jk.v7i2.3499

This is an open-access article under the CC-BY-SA License.

\section{Pendahuluan}

Pandemi Covid-19 telah menciptakan gangguan terbesar sepanjang sejarah pada sistem pendidikan, yang berdampak pada hampir 1,6 miliar pelajar di lebih dari 190 negara di seluruh benua (United Nations, 2020). Sebagai upaya pencegahan penyebaran Covid-19, khususnya pada satuan pendidikan, pemerintah Indonesia menetapkan kebijakan belajar dari rumah secara daring. Melalui pembelajaran daring (e-learning) diharapkan pendidikan dapat 
terus berjalan, walaupun di tengah masa pandemi. Namun, beralih dari pembelajaran tatap muka menuju pembelajaran daring (e-learning) secara penuh dalam waktu yang singkat bukanlah hal yang mudah, sebab diperlukan adanya persiapan yang matang guna mendorong keberhasilan e-learning. Berdasarkan hasil survei yang dilakukan Balitbang Kemendikbud, mayoritas siswa mengalami kesulitan dalam memahami pelajaran selama belajar dari rumah, hal ini disebabkan kurangnya konsentrasi, serta hambatan dalam komunikasi seperti siswa tidak bisa berinteraksi dan bertanya secara langsung kepada guru (Hutabarat, 2020).

Keberhasilan e-learning berkaitan erat dengan kesiapan e-learning (e-learning readiness) yang dimiliki siswa. Kaur dan Abas (2004) mendefinisikan kesiapan e-learning sebagai kemampuan individu untuk memanfaatkan sumber daya e-learning dan multimedia teknologi untuk meningkatkan kualitas pembelajaran. Secara teknis kesiapan e-learning adalah kemampuan calon pengguna e-learning dalam menggunakan lingkungan belajar baru serta penggunaan teknologi alternatif (Hashim \& Tasir, 2014). Menurut Budhianto (2020) salah satu faktor yang mempengaruhi keberhasilan pembelajaran daring adalah kesiapan diri dari pengguna sistem. Morris, Wu, dan Catherine (2005) menyatakan bahwa mereka yang berhasil dalam lingkungan pembelajaran online adalah mereka yang telah dipersiapkan dengan baik dan siap mengikuti pembelajaran online dan tanpa tatap muka, terampil dalam penggunaan teknologi dan browsing internet, serta mampu belajar secara mandiri. Kesiapan e-learning merupakan indikator penting dalam suksesnya pelaksanaan e-learning (Demir, 2015).

SMAN 14 Surabaya merupakan salah satu sekolah yang menerapkan fully-online $e$ learning, dimana proses pembelajaran sepenuhnya dilakukan secara daring (e-learning). Seluruh mata pelajaran tanpa terkecuali diajarkan melalui kelas daring. Beberapa media pembelajaran daring yang digunakan antara lain, Moodle, Google Classroom, dan Google Meet. Ini adalah pertama kalinya bagi SMAN 14 Surabaya menerapkan fully-online $e$ learning. Berdasarkan hasil obervasi yang telah dilakukan peneliti, diketahui bahwa selama diterapkannya pembelajaran daring secara penuh, performa belajar ekonomi sebagian besar siswa mengalami penurunan. Hal ini dapat dilihat dari lebih rendahnya partisipasi siswa dan hasil ujian siswa, serta ketidaksiplinan siswa dalam pengumpulan tugas selama pembelajaran daring.

Berdasarkan hasil wawancara dengan siswa, kendala yang dialami siswa antara lain adalah siswa mengalami kesulitan dalam mengelolah proses belajarnya secara mandiri, khususnya pada pembelajaran ekonomi; siswa belum terbiasa dengan adanya fully-online $e$ learning, mereka juga belum pernah memiliki pengalaman mengikuti fully-online e-learning sebelumnya; bagi siswa memahami materi pembelajaran ekonomi secara daring jauh lebih sulit dibandingkan dengan pembelajaran secara tatap muka, karena pembelajaran ekonomi membutuhkan pemahaman yang mendalam, melibatkan perhitungan dan analisis.

Dalam pembelajaran daring sangat penting untuk memastikan bahwa siswa merasa nyaman dengan proses pembelajaran dan teknologi e-learning yang digunakan karena keinginan siswa adalah kunci keberhasilan pembelajaran (Tuntirojanawong, 2013). Kesiapan e-learning yang dimiliki siswa terbentuk dari beberapa faktor, seperti kemampuan mengoperasikan software atau komputer, kemandirian belajar, hingga faktor pendorong kepuasan e-learning seperti motivasi dan persepsi. Beberapa peneliti menjadikan karakteristik umum siswa, keterampilan teknologi dasar, dan kemampuan siswa dalam memanajemen dan mengarahkan belajarnya secara mandiri sebagai fokus pengukuran kesiapan e-learning (Dray et al., 2011; Hung et al., 2010; Watkins et al., 2008). Menurut Alem et al. (2016) kesiapan e-learning terdiri dari lima dimensi yakni self-competency, perceived usefulness, self-directed learning, motivation, dan financial. 
Meskipun saat ini penelitian mengenai e-learning di Indonesia berkembang cukup pesat, namun penelitian mengenai kesiapan e-learning dan performa belajar siswa masih minim jumlahnya, terlebih pada pembelajaran daring selama pandemi Covid-19. Maka, sebagai upaya untuk mendorong peningkatan perfoma belajar ekonomi siswa selama pembelajaran daring penting untuk dilakukan pengukuran dan analisis tingkat kesiapan $e$ learning siswa, serta menguji bagaimana pengaruhnya terhadap performa belajar ekonomi siswa. Adapun tujuan dari penelitian ini adalah untuk mengukur tingkat kesiapan e-learning siswa, serta menganalisis pengaruh masing-masing faktor kesiapan e-learning terhadap performa belajar ekonomi siswa, sehingga dapat dilakukan identifikasi manakah faktor kritis kesiapan e-learning pendorong perfoma belajar ekonomi siswa. Diketahuinya faktor kritis kesiapan e-learning yang dapat mendorong performa belajar siswa, dapat membantu sekolah untuk menentukan prioritas penanganan pada tingkat kesiapan e-learning siswa, sehingga diharapkan dapat mempermudah upaya optimalisasi performa belajar ekonomi siswa selama pandemi Covid-19.

\section{Metode Penelitian}

Metode yang digunakan dalam penelitian ini adalah penelitian deskriftif kuantitatif. Populasi dalam penelitian ini adalah siswa Kelas IPS SMAN 14 Surabaya yang terdiri dari 3 tingkatan kelas yaitu kelas X, XI, dan XII, dengan total sebanyak 350 orang siswa. Teknik pengambilan sampel yang digunakan dalam penelitian ini adalah Proportional Random Sampling. Jumlah sampel dalam penelitian ini sebanyak 177 orang siswa, ditentukan berdasarkan tabel Isaac dan Michael dengan tingkat kesalahan 5\% (Sugiyono, 2010).

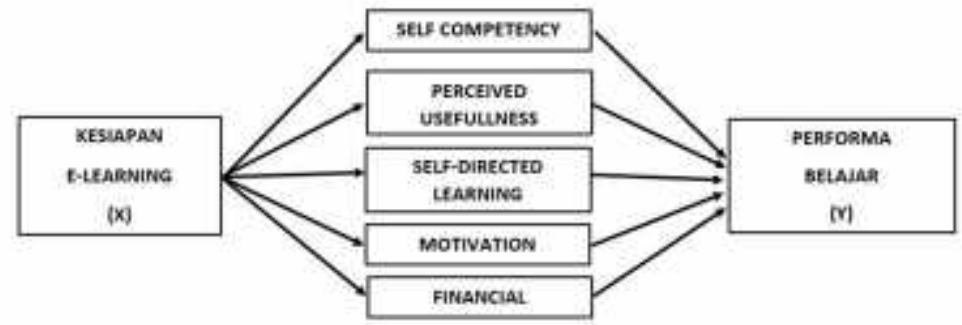

\section{Gambar 1. Model Penelitian}

Teknik pengumpulan data menggunakan kuesioner (angket) dengan skala likert yang telah dimodifikasi meliputi pernyataan Sangat Tidak Setuju (STS), Tidak Setuju (TS), Setuju (S) dan Sangat Setuju (SS), serta dokumentasi berupa laporan hasil belajar siswa. Teknik pengumpulan data melalui kuesioner digunakan untuk memperoleh data tentang faktor kesiapan e-learning siswa kelas IPS SMAN 14 Surabaya, sedangkan laporan hasil belajar siswa untuk memperoleh data tentang performa belajar ekonomi siswa yang terdiri dari nilai tugas dan nilai ujian (UTS/UAS). Instrumen kesiapan e-learning yang digunakan merupakan adaptasi dari intrumen kesiapan e-learning yang dikembangkan Alem et al. (2016) dengan menyesuaikan karakteristik siswa tingkat menengah di Indonesia. Sebelum digunakan, instrumen penelitian akan melalui uji validitas dan uji reliabilitas terlebih dahulu.

\section{Tabel 1. Komposisi Instrumen Penelitian}

\begin{tabular}{llc}
\hline \multicolumn{1}{c}{ Variabel } & \multicolumn{1}{c}{ Indikator } & Item Pertanyaan \\
\hline $\begin{array}{l}\text { Self- } \\
\text { Competency }\end{array}$ & $\begin{array}{l}\text { Kompeten dan percaya diri dalam menggunakan } \\
\text { komputer }\end{array}$ & $1,2,3$ \\
\hline $\begin{array}{l}\text { Perceived } \\
\text { Usefullness }\end{array}$ & $\begin{array}{l}\text { Kepercayaan bahwa penggunaan sistem tertentu } \\
\text { dapat membantu meningkatkan kinerja diri }\end{array}$ & $4,5,6$
\end{tabular}




\begin{tabular}{llc}
\hline $\begin{array}{l}\text { Self- } \\
\text { Directed } \\
\text { Learning }\end{array}$ & $\begin{array}{l}\text { Mampu mengarahkan kegiatan belajar secara } \\
\text { mandiri }\end{array}$ & $\begin{array}{l}\text { Mampu mengatur kegiatan belajar secara } \\
\text { mandiri }\end{array}$ \\
\hline Motivation & $\begin{array}{l}\text { Mampu menyelesaikan tugas dan memahami } \\
\text { materi sekalipun dalam hambatan }\end{array}$ & 10,11 \\
\hline Financial & $\begin{array}{l}\text { Mampu memperoleh komputer/gadget dan } \\
\text { akses internet untuk pembelajaran daring. }\end{array}$ & $12,13,14$ \\
\hline
\end{tabular}

Teknik analisis data yang digunakan adalah metode analisis regresi linier berganda. Pengujian hipotesis dilakukan dengan berdasarkan pada nilai probability signifikansi masingmasing variabel yang terdapat pada output hasil analisis regresi. Uji hipotesis meliputi uji t untuk mengetahui pengaruh variabel bebas (X) terhadap variabel terikat (Y) secara parsial, dan uji $\mathrm{F}$ untuk mengetahui pengaruh variabel bebas $(\mathrm{X})$ terhadap variabel terikat $(\mathrm{Y})$ secara simultan. Jika angka signifikansi lebih kecil dari $\alpha(0,05)$ maka dapat dikatakan bahwa terdapat pengaruh yang signifikan antara variabel bebas terhadap variabel terikat. Kemudian untuk mengetahui variabel kritis atau variabel manakah yang paling dominan menggunakan acuan nilai thitung, varibel dengan nilai thitung terbesar merupakan variabel yang memiliki pengaruh paling besar terhadap performa belajar ekonomi siswa. Selain itu, akan dilakukan uji koefisien determinasi (R Square) untuk mengetahui kemampuan variable bebas dalam menjelaskan variasi perubahan pada variable terikat.

\section{Hasil Penelitian dan Pembahasan}

Distribusi persentase kategori untuk masing-masing faktor kesiapan e-learning dapat dilihat pada tabel berikut.

Tabel 2. Distribusi Persentase Kategori Self-Competency

\begin{tabular}{cccc}
\hline Nilai & Jumlah Responden & Presentase & Kategori \\
\hline $\mathbf{X}>\mathbf{1 1}$ & 20 & $11.3 \%$ & Tinggi \\
\hline $\mathbf{6} \leq \mathbf{X} \leq \mathbf{1 1}$ & 140 & $79.1 \%$ & Sedang \\
\hline $\mathbf{X}<\mathbf{6}$ & 17 & $9.6 \%$ & Rendah \\
\hline Jumlah & 177 & $100 \%$ & \\
\hline
\end{tabular}

Berdasarkan pada tabel diatas, diketahui bahwa siswa dengan self-competency dalam kategori tinggi sebanyak 20 siswa dengan presentase 11,3\%, dalam kategori sedang sebanyak 140 siswa dengan presentase 79,1\%, dan dalam kategori rendah sebanyak 17 siswa dengan presentase $9,6 \%$. Dapat disimpulkan bahwa tingkat self-competency siswa kelas IPS SMAN 14 Surabaya berada dalam kategori sedang.

Tabel 3. Distribusi Persentase Kategori Perceived Usefulness

\begin{tabular}{cccc}
\hline Nilai & Jumlah Responden & $\begin{array}{c}\text { Presentase } \\
\text { Kategori }\end{array}$ & \begin{tabular}{c} 
Kanggi \\
\hline $\mathbf{X}>\mathbf{1 0}$
\end{tabular} \\
\hline $\mathbf{5} \leq \mathbf{X} \leq \mathbf{1 0}$ & 134 & $17 \%$ & Ting \\
\hline $\mathbf{X}<\mathbf{5}$ & 13 & $75.7 \%$ & Sedang \\
\hline Jumlah & 177 & $7.3 \%$ & Rendah \\
\hline
\end{tabular}

Berdasarkan pada tabel diatas, diketahui bahwa siswa dengan perceived usefulness dalam kategori tinggi sebanyak 30 siswa dengan presentase 17\%, dalam kategori sedang sebanyak 134 siswa dengan presentase 75,7\%, dan dalam kategori rendah sebanyak 13 siswa dengan presentase 7,3\%. Dapat disimpulkan bahwa tingkat perceived usefulness siswa kelas IPS SMAN 14 Surabaya berada dalam kategori sedang. 
Tabel 4. Distribusi Persentase Kategori Self-Directed Learning

\begin{tabular}{cccc}
\hline Nilai & Jumlah Responden & Presentase & Kategori \\
\hline $\mathbf{X}>\mathbf{1 8}$ & 42 & $23.7 \%$ & Tinggi \\
\hline $\mathbf{1 1} \leq \mathbf{X} \leq \mathbf{1 8}$ & 118 & $66.7 \%$ & Sedang \\
\hline $\mathbf{X}<\mathbf{1 1}$ & 17 & $9.6 \%$ & Rendah \\
\hline Jumlah & 177 & $100 \%$ & \\
\hline
\end{tabular}

Berdasarkan pada tabel diatas, diketahui bahwa siswa dengan self-directed learning dalam kategori tinggi sebanyak 42 siswa dengan presentase $23,7 \%$, dalam kategori sedang sebanyak 118 siswa dengan presentase 66,7\%, dan dalam kategori rendah sebanyak 17 siswa dengan presentase 9,6\%. Dapat disimpulkan bahwa tingkat self-directed learning siswa kelas IPS SMAN 14 Surabaya berada dalam kategori sedang.

Tabel 5. Distribusi Persentase Kategori Motivation

\begin{tabular}{cccc}
\hline Nilai & Jumlah Responden & Presentase & Kategori \\
\hline $\mathbf{X}>\mathbf{1 0}$ & 32 & $18.1 \%$ & Tinggi \\
\hline $\mathbf{5} \leq \mathbf{X} \leq \mathbf{1 0}$ & 129 & $72.9 \%$ & Sedang \\
\hline $\mathbf{X}<\mathbf{5}$ & 16 & $9 \%$ & Rendah \\
\hline Jumlah & 177 & $100 \%$ &
\end{tabular}

Berdasarkan pada tabel diatas, diketahui bahwa siswa dengan motivation dalam kategori tinggi sebanyak 32 siswa dengan presentase $18,1 \%$, dalam kategori sedang sebanyak 129 siswa dengan presentase 72,9\%, dan dalam kategori rendah sebanyak 16 siswa dengan presentase 9\%. Dapat disimpulkan bahwa tingkat motivation siswa kelas IPS SMAN 14 Surabaya berada dalam kategori sedang.

Tabel 6. Distribusi Persentase Kategori Financial

\begin{tabular}{cccc}
\hline Nilai & Jumlah Responden & Presentase & Kategori \\
\hline $\mathbf{X}>\mathbf{1 7}$ & 27 & $15.3 \%$ & Tinggi \\
\hline $\mathbf{1 1} \leq \mathbf{X} \leq \mathbf{1 7}$ & 132 & $74.6 \%$ & Sedang \\
\hline $\mathbf{X}<\mathbf{1 1}$ & 18 & $10.2 \%$ & Rendah \\
\hline Jumlah & 177 & $100 \%$ & \\
\hline
\end{tabular}

Berdasarkan pada tabel diatas, diketahui bahwa siswa dengan financial dalam kategori tinggi sebanyak 27 siswa dengan presentase 15,3\%, dalam kategori sedang sebanyak 132 siswa dengan presentase 74,6\%, dan dalam kategori rendah sebanyak 18 siswa dengan presentase $10,2 \%$. Dapat disimpulkan bahwa tingkat financial siswa kelas IPS SMAN 14 Surabaya berada dalam kategori sedang.

Tabel 7. Distribusi Persentase Kategori Nilai Tugas

\begin{tabular}{cccc}
\hline Nilai & Jumlah Responden & Presentase & Kategori \\
\hline $\mathbf{X}>\mathbf{8 8}$ & 15 & $8.5 \%$ & Tinggi \\
\hline $\mathbf{7 9} \leq \mathbf{X} \leq \mathbf{8 8}$ & 133 & $75.1 \%$ & Sedang \\
\hline $\mathbf{X}<\mathbf{7 9}$ & 29 & $16.4 \%$ & Rendah \\
\hline Jumlah & 177 & $100 \%$ & \\
\hline
\end{tabular}

Berdasarkan pada tabel diatas, diketahui bahwa siswa dengan nilai tugas dalam kategori tinggi sebanyak 15 siswa dengan presentase 8,5\%, dalam kategori sedang sebanyak 133 siswa dengan presentase $75,1 \%$, dan dalam kategori rendah sebanyak 29 siswa dengan presentase $16,4 \%$. Dapat disimpulkan bahwa tingkat performa belajar siswa kelas IPS SMAN 14 Surabaya pada aspek nilai tugas berada dalam kategori sedang.

Tabel 8. Distribusi Persentase Kategori Nilai Ujian

\begin{tabular}{cccc} 
Nilai & Jumlah Responden & Presentase & Kategori \\
$\mathbf{X}>\mathbf{8 5}$ & 22 & $12.4 \%$ & Tinggi \\
\hline
\end{tabular}




\begin{tabular}{cccc}
$\mathbf{6 7} \leq \mathbf{X} \leq \mathbf{8 5}$ & 131 & $74 \%$ & Sedang \\
\hline $\mathbf{X}<\mathbf{6 7}$ & 24 & $13.6 \%$ & Rendah \\
\hline Jumlah & 177 & $100 \%$ &
\end{tabular}

Berdasarkan pada tabel diatas, diketahui bahwa siswa dengan nilai ujian dalam kategori tinggi sebanyak 22 siswa dengan presentase $12,4 \%$, dalam kategori sedang sebanyak 131 siswa dengan presentase $74 \%$, dan dalam kategori rendah sebanyak 24 siswa dengan presentase 13,6\%. Dapat disimpulkan bahwa tingkat performa belajar siswa kelas IPS SMAN 14 Surabaya pada aspek nilai ujian berada dalam kategori sedang.

Tabel 9. Hasil Uji Prasyarat Regresi terhadap Y1 (Nilai Tugas)

\begin{tabular}{|c|c|c|c|c|}
\hline Variabel & $\begin{array}{l}\text { Normalitas } \\
\text { *Kolmogorov- } \\
\text { Smirnov }\end{array}$ & $\begin{array}{l}\text { Multikolinieritas } \\
\text { *Varience inflation } \\
\text { factor (VIF) }\end{array}$ & $\begin{array}{c}\text { Heteroskedastisitas } \\
\text { *Rank Spearman }\end{array}$ & $\begin{array}{c}\text { Liniertitas } \\
* \text { Test of } \\
\text { Linearity }\end{array}$ \\
\hline X1 & \multirow{5}{*}{0.063} & 1.522 & 0.935 & 0.000 \\
\hline $\mathrm{X} 2$ & & 2.477 & 0.578 & 0.000 \\
\hline $\mathrm{X3}$ & & 2.417 & 0.528 & 0.000 \\
\hline X4 & & 2.134 & 0.903 & 0.000 \\
\hline X5 & & 1.891 & 0.923 & 0.000 \\
\hline
\end{tabular}

Hasil uji normalitas menunjukkan nilai Asymp. Sig (2-tailed) sebesar 0,063, nilai tersebut lebih besar dari alpha $(0,063>0,05)$ yang berarti bahwa data terdistribusi normal. Hasil uji multikolinieritas menunjukkan nilai VIF pada variabel X1 sebesar 1,522, pada X2 sebesar 2,477, pada X3 sebesar 2,417, pada X4 sebesar 2,134, dan pada X5 sebesar 1,891. Berdasarkan hasil tersebut diketahui bahwa nilai VIF dari semua variabel kurang dari 10, yang berarti bahwa tidak terjadi masalah multikolinieritas dalam model regresi. Hasil uji heteroskedastisitas menunjukkan nilai signifikansi atau Sig. (2-tailed) variabel X1 sebesar 0,935, X2 sebesar 0,578, X3 sebesar 0,528, X4 sebesar 0,903, dan X5 sebesar 0,923. Nilai signifikansi seluruh variabel $\mathrm{X}$ lebih besar dari 0,05 yang berarti bahwa tidak terjadi gejala heteroskedastisitas didalam model regresi. Uji linieritas menunjukkan nilai signifikansi linearity pada seluruh variabel $\mathrm{X}$ sebesar 0,000 lebih kecil dari 0,05 yang berarti bahwa bahwa seluruh variabel $\mathrm{X}$ berhubungan secara linear pada nilai tugas.

Tabel 10. Hasil Uji Prasyarat Regresi terhadap Y2 (Nilai Ujian)

\begin{tabular}{|c|c|c|c|c|}
\hline Variabel & $\begin{array}{l}\text { Normalitas } \\
\text { *Kolmogorov- } \\
\text { Smirnov }\end{array}$ & $\begin{array}{l}\text { Multikolinieritas } \\
\text { *Varience inflation } \\
\text { factor (VIF) }\end{array}$ & $\begin{array}{c}\text { Heteroskedastisitas } \\
\text { *Rank Spearman }\end{array}$ & $\begin{array}{c}\text { Liniertitas } \\
* \text { Test of } \\
\text { Linearity }\end{array}$ \\
\hline X1 & \multirow{5}{*}{0.390} & 1.522 & 0.681 & 0.000 \\
\hline $\mathrm{X} 2$ & & 2.477 & 0.772 & 0.000 \\
\hline X3 & & 2.417 & 0.685 & 0.000 \\
\hline $\mathrm{X} 4$ & & 2.134 & 0.590 & 0.000 \\
\hline X5 & & 1.891 & 0.870 & 0.000 \\
\hline
\end{tabular}

Hasil uji normalitas menunjukkan nilai Asymp. Sig (2-tailed) sebesar 0,390, nilai tersebut lebih besar dari alpha $(0,063>0,05)$ yang berarti bahwa data terdistribusi normal. Hasil uji multikolinieritas menunjukkan nilai VIF pada variabel X1 sebesar 1,522, pada X2 sebesar 2,477, pada X3 sebesar 2,417, pada X4 sebesar 2,134, dan pada X5 sebesar 1,891. Berdasarkan hasil tersebut diketahui bahwa nilai VIF dari semua variabel kurang dari 10, yang berarti bahwa tidak terjadi masalah multikolinieritas dalam model regresi. Hasil uji heteroskedastisitas menunjukkan nilai signifikansi atau Sig. (2-tailed) variabel X1 sebesar 0,681, X2 sebesar 0,772, X3 sebesar 0,685, X4 sebesar 0,590, dan X5 sebesar 0,870. Nilai signifikansi seluruh variabel $\mathrm{X}$ lebih besar dari 0,05 yang berarti bahwa tidak terjadi gejala heteroskedastisitas didalam model regresi. Uji linieritas menunjukkan nilai signifikansi 
linearity pada seluruh variabel $X$ sebesar 0,000 lebih kecil dari 0,05 yang berarti bahwa bahwa seluruh variabel $X$ berhubungan secara linear pada nilai ujian.

Tabel 11. Hasil Uji Regresi Linier Berganda terhadap Y1 (Nilai Tugas)

\begin{tabular}{|c|c|c|c|c|c|c|}
\hline Variabel & $\boldsymbol{\beta}$ & $\mathbf{t}$ & Sig. & $\mathbf{F}$ & Sig. & R Square \\
\hline (Constant) & 73.856 & 46.276 & 0.000 & \multirow{6}{*}{8.764} & \multirow{6}{*}{$.000 \mathrm{a}$} & \multirow{6}{*}{0.204} \\
\hline Self Competency (X1) & 0.141 & 0.907 & 0.366 & & & \\
\hline Perceived Usefulness (X2) & 0.341 & 1.809 & 0.072 & & & \\
\hline $\begin{array}{l}\text { Self-Directed Learning } \\
\text { (X3) }\end{array}$ & 0.127 & 1.000 & 0.319 & & & \\
\hline Motivation (X4) & 0.044 & 0.239 & 0.811 & & & \\
\hline Financial (X5) & 0.233 & 1.564 & 0.120 & & & \\
\hline
\end{tabular}

Tabel 12. Hasil Uji Regresi Linier Berganda terhadap Y2 (Nilai Ujian)

\begin{tabular}{|c|c|c|c|c|c|c|}
\hline Variabel & $\boldsymbol{\beta}$ & $\mathbf{t}$ & Sig. & $\mathbf{F}$ & Sig. & $\begin{array}{c}\mathbf{R} \\
\text { Square }\end{array}$ \\
\hline (Constant) & 42.413 & 20.857 & 0.000 & \multirow{6}{*}{72.007} & \multirow{6}{*}{$0.000 \mathrm{a}$} & \multirow{6}{*}{0.678} \\
\hline Self Competency (X1) & 0.982 & 4.952 & 0.000 & & & \\
\hline Perceived Usefulness (X2) & 0.701 & 2.916 & 0.004 & & & \\
\hline $\begin{array}{l}\text { Self-Directed Learning } \\
\text { (X3) }\end{array}$ & 0.856 & 5.272 & 0.000 & & & \\
\hline Motivation (X4) & 0.017 & 0.073 & 0.942 & & & \\
\hline Financial (X5) & 0.564 & 2.978 & 0.003 & & & \\
\hline
\end{tabular}

\section{Self-Competency dan Performa Belajar Ekonomi}

Berdasarkan hasil Uji t statistik terhadap Y1 (Nilai Tugas) pada Tabel 11. diketahui self-competency memiliki nilai signifikansi sebesar 0,366 >0,05 yang berarti bahwa selfcompetency secara parsial tidak berpengaruh terhadap nilai tugas. Sedangkan, hasil Uji t statistik terhadap Y2 (Nilai Ujian) pada Tabel 12. diketahui self-competency memiliki nilai signifikansi sebesar $0,000<0,05$ yang berarti bahwa self-competency secara parsial berpengaruh signifikan terhadap nilai ujian.

Hasil penelitian ini menunjukkan bahwa self-competency memiliki pengaruh positif signifikan terhadap performa belajar ekonomi pada aspek nilai ujian. Meskipun secara parsial tidak berpengaruh pada aspek nilai tugas, hasil penelitian ini membuktikan bahwa selfcompetency merupakan faktor dominan kedua yang mempengaruhi performa belajar siswa pada aspek nilai ujian dengan nilai $\mathrm{t}^{\text {hitung }}=4,952$. Hasil penelitian ini sejalan dengan penelitian C. H. Wang dkk (2013) yang menunjukkan bahwa siswa dengan tingkat technology self-efficacy yang lebih tinggi akan memperoleh nilai akhir yang lebih baik.

Pengetahuan individu, serta pengalaman komputer dan keterampilan internet sebelumnya yang dimiliki siswa berkontribusi pada peningkatan kecenderungan berpikir, yang meliputi pola berpikir intelektual, yang merupakan faktor penting keberhasilan siswa dalam lingkungan yang terkomputerisasi (Bouhnik \& Carmi, 2014). Dalam pembelajaran daring yang sepenuhnya menggunakan perangkat komputer dan internet selama kegiatan pembelajaran, kepercayaan diri siswa dalam menggunakan berbagai perangkat tersebut mendorong siswa untuk dapat lebih mudah mencapai performa atau kinerja yang baik selama pembelajaran (Wei \& Chou, 2020). Hal ini juga dibuktikan dengan penelitian yang dilakukan Roumiana Peytcheva-Forsyth et al. (2018), yakni bahwa keterampilan dan pengalaman siswa dengan teknologi dan web atau aplikasi tertentu dalam konteks pendidikan merupakan prediktor yang signifikan dalam memprediksi sikap siswa terhadap pembelajaran online. 


\section{Perceived Usefulness dan Performa Belajar Ekonomi}

Berdasarkan hasil Uji t statistik terhadap Y1 (Nilai Tugas) pada Tabel 11. diketahui perceived usefulness memiliki nilai signifikansi sebesar $0,072>0,05$ yang berarti bahwa perceived usefulness secara parsial tidak berpengaruh terhadap nilai tugas. Sedangkan, hasil Uji t statistik terhadap Y2 (Nilai Ujian) pada Tabel 12. diketahui perceived usefulness memiliki nilai signifikansi sebesar 0,004 $<0,05$ yang berarti bahwa perceived usefulness secara parsial berpengaruh signifikan terhadap nilai ujian.

Hasil penelitian ini menunjukkan bahwa perceived usefulness memiliki pengaruh positif signifikan terhadap performa belajar ekonomi pada aspek nilai ujian, namun tidak pada aspek nilai tugas. Meskipun secara parsial tidak berpengaruh pada aspek nilai tugas, hasil penelitian ini membuktikan bahwa perceived usefulness merupakan salah satu aspek yang mampu mendorong performa belajar siswa. Hasil penelitian ini sejalan dengan peneltian Abdullah dan Toycan (2018) yang menunjukkan bahwa perceived usefulness memiliki pengaruh langsung yang positif terhadap behavioral intention, dan attitude pada e-learning yang mendorong keberlanjutan dari pelaksanaan e-learning.

Faktor perceived usefulness berperan mendorong keberlanjutan dari pelaksanaan $e$ learning. Prinsip dasarnya, pengguna akan lebih cenderung menggunakan teknologi baru jika dapat membantu mereka melakukan pekerjaan dan mudah digunakan (Ngampornchai \& Adams, 2016). E-learning akan diterima siswa dan dapat meningkatkan hasil belajar mereka, bila e-learning dianggap berguna bagi mereka (Toni Mohr, Holtbrügge, \& Berg, 2012). Siswa akan berperforma baik dalam pembelajaran daring ketika mereka merasa bahwa pelaksanaan pembelajaran daring mampu memberikan manfaat bagi mereka. Hal ini didukung dengan pernyataan Tabak dan Nguyen (2013) yang menyatakan bahwa perlu bagi siswa untuk mengevaluasi kegunaan teknologi serta kemudahan penggunaannya sebelum dan selama pembelajaran online agar dapat memberi dampak pada performa siswa dalam pembelajaran online.

\section{Self-Directed Learning dan Performa Belajar Ekonomi}

Berdasarkan hasil Uji t statistik terhadap Y1 (Nilai Tugas) diketahui self-directed learning memiliki nilai signifikansi sebesar 0,319>0,05 yang berarti bahwa self-directed learning secara parsial tidak berpengaruh terhadap nilai tugas. Sedangkan, hasil Uji t statistik terhadap Y2 (Nilai Ujian) diketahui self-directed learning memiliki nilai signifikansi sebesar $0,000<0,05$ yang berarti bahwa self-directed learning secara parsial berpengaruh signifikan terhadap nilai ujian.

Hasil penelitian ini menunjukkan bahwa self-directed learning memiliki pengaruh positif signifikan terhadap performa belajar ekonomi pada aspek nilai ujian, namun tidak pada aspek nilai tugas. Meskipun secara parsial tidak berpengaruh pada aspek nilai tugas, hasil penelitian ini membuktikan bahwa self-directed learning merupakan faktor kritis atau faktor yang paling dominan yang mempengaruhi performa belajar siswa pada aspek nilai ujian dengan nilai $\mathrm{t}^{\text {hitung }}=5,272$. Hasil penelitian ini sejalan dengan penelitian oleh Gigdem dan Osturk (2016) yang menunjukkan bahwa, self-directed learning merupakan prediktor terkuat prestasi belajar online siswa.

Self-directed learning merupakan kemampuan siswa dalam mengarahkan dan mengatur belajarnya secara mandiri (Knowles, 1975). Ketidaksiapan siswa dalam menghadapi tuntutan dan pengalaman belajar yang terisolasi menyebabkan frustasi dan kegagalan dalam pembelajaran online, self-directed learning menjadi fondasi yang dapat membantu membangun fitur dari sistem yang dipersonalisasi serta meningkatkan kemampuan mereka untuk mengelola seluruh aktivitas pembelajaran dan memantau performa mereka secara mandiri (Kim, Olfman, Ryan, \& Eryilmaz, 2014). 
Dalam lingkungan pembelajaran online, proses pembelajaran tercermin dari kemandirian pelajar, kemampuan siswa dalam mengatur diri memainkan peran penting dalam memanfaatkan lingkungan belajar (Dikbas Torun, 2020). Dalam pembelajaran online, interaksi siswa dan guru sangatlah minim. Hal ini tentunya menjadi hambatan bagi siswa untuk dapat memperoleh arahan dan bimbingan dalam proses belajar mereka. Pada kondisi ini siswa dituntut untuk dapat mengelolah dan mengarahkan proses belajarnya mandiri, inilah mengapa self-directed learning menjadi faktor sangat penting untuk mendorong performa belajar siswa. Pernyataan ini diperkuat oleh Özkan Kırmızı (2015) yang menyatakan selfdirected learning sebagai prediktor prestasi akademik siswa yang paling penting dalam kesuksesan pembelajaran online.

\section{Motivation dan Performa Belajar Ekonomi}

Berdasarkan hasil Uji t statistik terhadap Y1 (Nilai Tugas) pada Tabel 11. diketahui motivation memiliki nilai signifikansi sebesar 0,811 > 0,05 yang berarti bahwa motivation secara parsial tidak berpengaruh terhadap nilai tugas. Sedangkan, hasil Uji t statistik terhadap Y2 (Nilai Ujian) pada Tabel 12. diketahui motivation memiliki nilai signifikansi sebesar $0,942>0,05$ yang berarti bahwa motivation secara parsial tidak berpengaruh terhadap nilai ujian.

Hasil penelitian ini menunjukkan bahwa motivation tidak memiliki pengaruh terhadap performa belajar ekonomi baik pada aspek nilai tugas maupun pada aspek nilai ujian. Hasil penelitian tidak sejalan dengan penelitian oleh Özkan Kırmızı (2015) yang menyatakan bahwa motivasi merupakan faktor penting yang mempengaruhi prestasi akademik siswa. Meski demikian, hasil penelitian ini sejalan dengan penelitian Gigdem dan Osturk (2016) yang menyatakan bahwa motivasi tidak berpengaruh terhadap prestasi belajar siswa. Namun dalam penelitiannya, peneliti tidak memberi penjelasan secara detail mengenai alasan mengapa motivasi tidak berpengaruh terhadap prestasi belajar siswa.

Apabila mengacu pada data yang yang diperoleh, diketahui bahwa terdapat sebagian siswa yang memiliki nilai dalam performa belajar yang terpaut cukup jauh, namun memiliki tingkat motivasi yang sama, dan siswa yang memiliki performa belajar dalam kategori sama namun memiliki tingkat motivasi yang jauh berbeda. Sehingga, perbedaan tingkat motivasi tidak memberikan pengaruh yang berarti bagi performa belajar ekonomi siswa (nilai tugas dan nilai ujian).

Hal tersebut dapat disebabkan karena kurangnya rasa percaya diri siswa terhadap kemampuannya dalam menyelesaikan tugas dan memahami materi ketika terjadi hambatan. Suryani et. al (2020) menyatakan bahwa efikasi diri (keyakinan diri untuk dapat menyelesaikan tugas) memiliki korelasi yang signifikan terhadap hasil belajar. Mereka mungkin menilai diri mereka tidak mampu menyelesaikan tugas dan memahami materi, namun nyatanya dalam praktiknya mereka berhasil memiliki performa belajar yang baik. Palavan (2017) menyatakan bahwa kurangnya rasa percaya diri siswa dapat menyebabkan kurangnya motivasi siswa yang akibatnya dapat menyebabkan siswa menunjukkan sikap negatif terhadap aktivitas belajar.

Selain itu, adanya faktor lain yang juga turut mempengaruhi motivasi juga dapat menyebabkan tidak berpengaruhnya variabel motivasi terhadap performa belajar, salah satunya adalah kepuasan siswa. Ketika suatu pembelajaran tidak berhasil untuk memenuhi harapan dan kebutuhan siswa, hal itu dapat mengakibatkan penurunan tingkat partisipasi dan motivasi siswa (Bradford, 2011).

\section{Financial dan Performa Belajar Ekonomi}

Berdasarkan hasil Uji $\mathrm{t}$ statistik terhadap Y1 (Nilai Tugas) diketahui financial memiliki nilai signifikansi sebesar 0,120 >0,05 yang berarti bahwa financial secara parsial 
tidak berpengaruh terhadap nilai tugas. Sedangkan, hasil Uji t statistik terhadap Y2 (Nilai Ujian) diketahui financial memiliki nilai signifikansi sebesar $0,003<0,05$ yang berarti bahwa financial secara parsial berpengaruh signifikan terhadap nilai ujian.

Hasil penelitian ini menunjukkan bahwa faktor financial memiliki pengaruh positif signifikan terhadap performa belajar ekonomi pada aspek nilai ujian. Meskipun secara parsial tidak berpengaruh pada aspek nilai tugas, hasil penelitian ini membuktikan bahwa financial merupakan faktor dominan ketiga yang mempengaruhi performa belajar siswa pada aspek nilai ujian dengan nilai $t^{\text {hitung }}=2,972$. Hasil ini sejalan dengan penelitian Nnamani, Dikko, dan Kinta, (2014) yang menyatakan bahwa kecukupan keuangan memliki pengaruh positif terhadap kinerja akademik siswa.

Financial merujuk pada kemampuan siswa untuk menjangkau sarana dan prasarana pendidikan secara ekonomi. Dukungan keuangan merupakan faktor penting penentu keberhasilan siswa dalam menyelesaikan pembelajaran online (Morris et al., 2005). Pada pembelajaran daring, sarana dan prasarana utama yang digunakan adalah handphone, komputer/laptop, dan paket layanan data. Permasalahan seperti koneksi internet dan ponsel android yang tidak mendukung untuk digunakan dalam pembelajaran daring karena memiliki RAM yang kecil dapat membuat siswa merasa frustasi (Agung \& Surtikanti, 2020). Permasalahan tersebut tentunya dapat menganggu proses belajar siswa.

Siswa dapat berperforma baik dalam pembelajaran daring selama masa pandemi apabila mereka memiliki sarana dan prasana yang diperlukan. Namun, tidak semua mampu menjangkau sarana dan prasarana tersebut karena kendala finansial. Hal tersebutlah yang menyebabkan siswa dengan kondisi finansial yang baik cenderung memiliki performa belajar lebih yang baik daripada mereka yang berada pada kondisi finansial yang lemah. Hal ini dibuktikan dengan penelitian Harding (2011) yang menyatakan bahwa kesulitan keuangan berdampak pada penurunan performa akademik siswa.

\section{Kesiapan E-Learning dan Performa Belajar Ekonomi}

Hasil uji F (simultan) variabel X terhadap variabel Y1 (nilai tugas) pada Tabel 11. menunjukkan nilai signifikansi sebesar $0,000<0,05$ yang berarti bahwa variabel selfcompetency (X1), perceived usefulness (X2), self-directed learning (X3), motivation (X4), dan financial (X5) secara simultan berpengaruh signifikan terhadap nilai tugas (Y1). Hasil uji $\mathrm{F}$ (simultan) variabel $\mathrm{X}$ terhadap variabel Y2 (nilai ujian) pada Tabel 12. juga menunjukkan hasil yang sama dengan nilai signifikansi sebesar $0,000<0,05$ yang berarti bahwa variabel self-competency (X1), perceived usefulness (X2), self-directed learning (X3), motivation (X4), dan financial (X5) secara simultan berpengaruh signifikan terhadap nilai ujian (Y2).

Hasil uji determinasi ( $\mathrm{R}$ Square) variabel $\mathrm{X}$ terhadap variabel $\mathrm{Y} 1$ (nilai tugas) diperoleh nilai R Square sebesar 0.204, yang berarti bahwa 20,4\% variabel nilai tugas dipengaruhi oleh variabel self-competency, perceived usefulness, self-directed learning, motivation, dan financial. Sedangkan 79,6\% dipengaruhi oleh variabel lain diluar model. Hasil uji determinasi (R Square) variabel X terhadap variabel Y2 (nilai ujian) diperoleh nilai R Square sebesar 0.678, yang berarti bahwa 67,8\% variabel nilai ujian dipengaruhi oleh variabel self-competency, perceived usefulness, self-directed learning, motivation, dan financial. Sedangkan 32,2\% dipengaruhi oleh variabel lain diluar model. Hasil penelitian ini sejalan dengan penelitian (Demir, 2015) yang menyatakan bahwa kesiapan e-learning merupakan indikator penting dalam suksesnya pelaksanaan $e$-learning.

Agar dapat lebih memahami bagaimana cara untuk mencapai pembelajaran online yang efektif, sangat penting untuk mengetahui dimensi kesiapan e-learning apa yang harus dimiliki siswa (Hung dkk, 2010). Pembelajaran daring sangatlah berbeda dengan pembelajaran konvensional. Kemampuan mengatur diri dan ketrampilan internet/komputer 
sangat diperlukan untuk dapat menjalani proses belajar dengan baik. Dalam pembelajaran daring sangat penting untuk memastikan bahwa siswa merasa nyaman dengan proses pembelajaran dan teknologi e-learning yang digunakan karena kemauan siswa adalah kunci keberhasilan pembelajaran (Tuntirojanawong, 2013).

Kesiapan e-learning merupakan modal awal bagi siswa untuk dapat berhasil dalam pembelajaran daring. Kesiapan e-learning mendorong siswa untuk siap menghadapi lingkungan baru, memudahkan mereka dalam beradaptasi, serta memampukan mereka untuk bertahan dan meraih kesuksesan dalam pembelajaran daring. Mereka yang berhasil dalam lingkungan pembelajaran online adalah mereka yang telah dipersiapkan dengan baik dan siap mengikuti pembelajaran online dan tanpa tatap muka, terampil dalam penggunaan teknologi dan browsing internet, serta mampu belajar secara mandiri (Morris dkk, 2005).

\section{Kesimpulan}

Berdasarkan hasil penelitian ini diperoleh kesimpulan bahwa empat faktor kesiapan $e$ learning yakni self-competency, perceived usefulness, self-directed learning, dan financial secara parsial berpengaruh signifikan terhadap performa belajar ekonomi (nilai ujian) siswa kelas IPS SMAN 14 Surabaya. Sedangkan, faktor lainnya yakni motivation secara parsial tidak berpengaruh terhadap performa belajar ekonomi siswa (nilai tugas dan ujian). Hasil analisis menunjukkan self-directed learning sebagai faktor terkuat pendorong performa belajar ekonomi siswa (nilai ujian), yang kemudian secara berurutan diikuti oleh faktor selfcompetency, financial, dan perceived usefulness. Selanjutnya, hasil analisis menunjukkan bahwa seluruh faktor kesiapan e-learning secara simultan berpengaruh signifikan terhadap performa belajar ekonomi siswa (nilai tugas dan ujian).

\section{Saran}

Adapun saran yang diajukan berdasarkan hasil penelitian ini antara lain sebagai berikut: (1) Bagi sekolah untuk lebih memperhatikan faktor-faktor kesiapan e-learning yang dimiliki siswa meliputi self-competency, perceived usefulness, self-directed learning, motivation, dan financial. Faktor kesiapan e-learning yang dimiliki siswa termasuk dalam kategori sedang, maka perlu adanya upaya untuk memaksimalkan faktor-faktor tersebut agar dapat mendorong performa belajar ekonomi siswa menjadi lebih optimal. (2) Bagi peneliti selanjutnya diharapkan dapat mengembangkan penelitian tentang kesiapan e-learning dan perfoma belajar siswa khususnya pada mata pelajaran ekonomi lebih luas lagi, dengan mengunakan faktor lain, indikator lain, ataupun metode yang lain, dikarenakan masih adanya keterbatasan dan kelemahan dalam hasil penelitian ini.

\section{Daftar Pustaka}

Abdullah, M. S., \& Toycan, M. (2018). Analysis of the factors for the successful e-learning services adoption from education providers' and students' perspectives: A case study of private universities in Northern Iraq. Eurasia Journal of Mathematics, Science and Technology Education, 14(3), 1097-1109. https://doi.org/10.12973/ejmste/81554

Agung, A. S. N., \& Surtikanti, M. W. (2020). Students' Perception of Online Learning during COVID-19 Pandemic: A Case Study on the English Students of STKIP Pamane Talino. SOSHUM: Jurnal Sosial Dan Humaniora, 10(2), 225-235. https://doi.org/10.31940/soshum.v10i2.1316

Alem, F., Plaisent, M., Zuccaro, C., \& Bernard, P. (2016). Measuring e-Learning Readiness Concept: Scale Development and Validation Using Structural Equation Modeling. Jurnal Kependidikan Vol. 7. No. 2 : Juni 2021 
International Journal of E-Education, e-Business, e-Management and e-Learning, 6(4), 193-207. https://doi.org/10.17706/ijeeee.2016.6.4.193-207

Bouhnik, D., \& Carmi, G. (2014). Computer skills and prior experience with e-learning courses as factors that affect development of intellectual thinking dispositions in online learning. Multicultural Awareness and Technology in Higher Education: Global Perspectives, (July 2016), 302-323. https://doi.org/10.4018/978-1-4666-58769.ch015

Budhianto, B. (2020). Analisis Perkembangan dan Faktor yang Mempengaruhi Keberhasilan Pembelajaran Daring ( E - Learning ). Jurnal AgriWidya, 1(1), 11-29.

Demir, O. (2015). The investigation of e-learning readiness of students and faculty members: Hacettepe university, faculty of education example. Hacettepe University, Ankara.

Dikbas Torun, E. (2020). Online Distance Learning in Higher Education: E-learning Readiness as a Predictor of Academic Achievement. Open Praxis, 12(2), 191. https://doi.org/10.5944/openpraxis.12.2.1092

Dray, B. J., Lowenthal, P. R., Miszkiewicz, M. J., Ruiz-Primo, M. A., \& Marczynski, K. (2011). Developing an instrument to assess student readiness for online learning: A validation study. Distance Education, 32(1), 29-47. https://doi.org/10.1080/01587919.2011.565496

Gigdem, H., \& Osturk, M. (2016). Critical Components of Online Learning Readiness. Turkish Online Journal of Distance Education, 17(21), 98-109.

Harding, J. (2011). Financial circumstances, fi nancial dif fi culties and academic achievement among fi rst-year undergraduates. 35(4), 483-499.

Hashim, H., \& Tasir, Z. (2014). E-learning readiness: A literature review. Proceedings - 2014 International Conference on Teaching and Learning in Computing and Engineering, LATICE 2014, (April 2014), 267-271. https://doi.org/10.1109/LaTiCE.2014.58

Hung, M. L., Chou, C., Chen, C. H., \& Own, Z. Y. (2010). Learner readiness for online learning: Scale development and student perceptions. Computers and Education, 55(3), 1080-1090. https://doi.org/10.1016/j.compedu.2010.05.004

Hutabarat, D. (2020). Kemendikbud: Mayoritas Anak Sulit Pahami Pelajaran Selama Belajar dari Rumah. Retrieved September 21, 2020, from Liputan6.com website: https://www.liputan6.com/news/read/4300912/kemendikbud-mayoritas-anak-sulitpahami-pelajaran-selama-belajar-dari-rumah

Kaur, K., \& Abas, Z. W. (2004). An assessment of e-learning readiness at Open University Malaysia. In In Paper presented at the international conference on com-puters in education (ICCE2004), Melbourne, Australia. Retrieved from http://library.oum.edu.my/repository/id/eprint/115

Kim, R., Olfman, L., Ryan, T., \& Eryilmaz, E. (2014). Leveraging a personalized system to improve self-directed learning in online educational environments. Computers and Education, 70, 150-160. https://doi.org/10.1016/j.compedu.2013.08.006

Knowles M. (1975). Self-directed learning: A guide for learners and teachers. New York: Association Press. 
Morris, L. V, Wu, S., \& Catherine, L. (2005). Predicting Retention in Online General Education Courses. American Journal of Distance Education, (June 2012), 23-36. https://doi.org/10.1207/s15389286ajde1901

Ngampornchai, A., \& Adams, J. (2016). Students' acceptance and readiness for E-learning in Northeastern Thailand. International Journal of Educational Technology in Higher Education, 13(1). https://doi.org/10.1186/s41239-016-0034-x

Nnamani, C., Dikko, H., \& Kinta, L. (2014). Impact of Students' Financial Strength on their Academic Performance: Kaduna Polytechnic Experience. African Research Review, 8(1), 83. https://doi.org/10.4314/afrrev.v8i1.7

Palavan, Ö. (2017). Impact of Drama Education on The Self-Confidence and ProblemSolving Skills of Students of Primary School Education Dramanın Sınıf Öğretmeni Adaylarının Özgüvenlerine Ve Problem Çözme Becerilerine Etkisi. Kastamonu Education Journal, 25(1), 187-202.

Peytcheva-Forsyth, R., Yovkova, B., \& Aleksieva, L. (2018). Factors affecting students' attitudes towards online learning - The case of Sofia University. AIP Conference Proceedings, 2048(December). https://doi.org/10.1063/1.5082043

Sugiyono. (2010). Metode Penelitian Pendidikan (Pendidikan Kualitatif, Kuantitatif, dan $R \& D)$. Bandung: Alfabeta.

Suryani, L., Seto, S. B., \& Bantas, M. G. D. (2020). Hubungan Efikasi Diri dan Motivasi Belajar Terhadap Hasil Belajar Berbasis E-Learning pada Mahasiswa Program Studi Pendidikan Matematika Universitas Flores. Jurnal Kependidikan: Jurnal Hasil Penelitian Dan Kajian Kepustakaan Di Bidang Pendidikan, Pengajaran Dan Pembelajaran, 6(2), 275. https://doi.org/10.33394/jk.v6i2.2609

Tabak, F., \& Nguyen, N. T. (2013). Technology Acceptance and Performance in Online Learning Environments: Impact of Self-Regulation. Journal of Online Learning and Teaching, 9(1), 116-130. Retrieved from http://search.proquest.com.library.capella.edu/docview/1500386147?accountid=2796 5\%5Cnhttp://wv9lq5ld3p.search.serialssolutions.com.library.capella.edu/?ctx_ver=Z3 9.88-2004\&ctx_enc=info:ofi/enc:UTF-

8\&rfr_id=info:sid/ProQ:education\&rft_val_fmt=info:ofi/fmt:

Toni Mohr, A., Holtbrügge, D., \& Berg, N. (2012). Learning style preferences and the perceived usefulness of e-learning. Teaching in Higher Education, 17(3), 309-322. https://doi.org/10.1080/13562517.2011.640999

Tuntirojanawong, S. (2013). Students ' Readiness for E-learning: A Case Study of Sukhotai Thammathirat Open University, Thailand. Journal of Learning in Higher Education, 9(1), 59-66.

United Nations. (2020). Education during COVID-19 and beyond AUGUST 2020. (August), 2-26. Retrieved from https://unsdg.un.org/resources/policy-brief-education-duringcovid-19-and-beyond

Wang, C. H., Shannon, D. M., \& Ross, M. E. (2013). Students' characteristics, self-regulated learning, technology self-efficacy, and course outcomes in online learning. Distance Education, 34(3), 302-323. https://doi.org/10.1080/01587919.2013.835779 
Watkins, R., Leigh, D., \& Triner, D. (2004). Assessing Readiness for E-Learning. Performance Improvement Quarterly, 17(4), 66-79. https://doi.org/10.1111/j.19378327.2004.tb00321.x

Wei, H. C., \& Chou, C. (2020). Online learning performance and satisfaction: do perceptions and readiness matter? Distance Education, 41(1), 48-69. https://doi.org/10.1080/01587919.2020.1724768 